\title{
Initial findings from agricultural water quality monitoring at the edge-of-field in Arkansas
}

\author{
M.L. Reba, N. Aryal, T.G. Teague, and J.H. Massey
}

\begin{abstract}
With farm-scale knowledge of how production practices affect water quality, land managers and agricultural producers can make more informed decisions on implementing soil and water conservation practices that sustain productivity and protect water resources. The Lower Mississippi River Basin is a major agricultural production region for rice (Oryza sativa L.), cotton (Gossypium hirsutum L.), and soybean (Glycine max [L.] Merr.); however, there is limited knowledge on how agronomic practices in those southern cropping systems affect water quality. Results from environmental models indicate commercial fertilizer from agricultural fields contributes substantially to the hypoxic zone in the northern Gulf of Mexico. To expand understanding of runoff water quality at the field scale, edge-of-field water quality monitoring studies were carried out in nine commercial rice, cotton, and soybean fields in northeastern Arkansas over multiple seasons. These year-round monitoring activities generated 23 site-years of data on sediment and nutrient concentrations and loads with various soils and crop rotation regimes. Discharge from runoff, nitrite-nitrogen $\left(\mathrm{NO}_{2}-\mathrm{N}\right)$, nitrate-nitrogen $\left(\mathrm{NO}_{3}-\mathrm{N}\right)$, total $\mathrm{N}$, soluble phosphorus $(\mathrm{P})$, total phosphorus $(\mathrm{TP})$, and suspended sediment concentration on a per-event basis were measured. The results indicate that the nongrowing season loads and concentrations of several measured components were statistically higher than those measured during the growing season, lending support to the need for off-season practices such as winter cover crops and winter shallow water storage. Lower concentrations and loads of nutrients and sediment were observed in rice fields compared to cotton and soybean systems. These differences are likely due to soil type but are also related to the water management system of flooded rice fields compared to furrow irrigated row crops. These findings provide baseline runoff water quality data and will help inform regional budgets of nutrients and sediment loss. Such information can assist land managers and conservationists in directing resources more effectively. These data also will support modelers in their efforts to calibrate, verify, validate, and estimate uncertainty for simulations of nutrients and sediment loss.
\end{abstract}

Key words: agricultural runoff-edge-of-field (EOF) monitoring-nonpoint source pollution-nutrient loss—-sediment loss

\begin{abstract}
Agriculture is challenged to increase productivity per unit area while using fewer inputs and reducing its overall environmental footprint. Agricultural intensification can result in negative environmental impacts, such as nonpoint source pollution (Douglas et al. 1998; MateoSagasta et al. 2017; Moore et al. 2007; USEPA 2009). For example, nutrients and sediment lost in irrigation runoff from agricultural fields can impact water quality in downstream waterways. Such losses present both an agro-economic and an environmental challenge. When agricultural managers apply costly fertilizers in fields, their expectation is
\end{abstract} and not be lost in surface water runoff Coupled with erosion of precious topsoil, losses of excess nutrients are manifested in turbid, hypoxic (low oxygen [O]) and anoxic (no $\mathrm{O}$ ) waters as well as sediment buildup in water resources.

Examples of eutrophication of coastal waters include the Baltic Sea (Larsson et al. 1985), the Adriatic Sea (Faganeli et al. 1985), and the Black Sea (Tolmazin 1985).The most notable hypoxic zone in the United States is in the "Dead Zone" located in the northern Gulf of Mexico (Rabalais et al. 2002). The annual size of the hypoxic zone in the northern Gulf of Mexico is most tightly linked to the nitrate $\left(\mathrm{NO}_{3}\right)$ and nitrite $\left(\mathrm{NO}_{2}\right)$ loads measured at Baton Rouge, Louisiana, in May (Turner et al. 2008). Modelling work by Rebich et al. (2011) estimated that agricultural fertilizers from farmlands in the Lower Mississippi River watershed contribute 32\% and $50 \%$ of delivered load of nitrogen $(\mathrm{N})$ and phosphorus $(\mathrm{P})$, respectively. Early plans for reducing the hypoxic zone in the northern Gulf of Mexico focused on $\mathrm{N}$ reduction; a dual nutrient strategy is currently endorsed, though $\mathrm{N}$ is still the ultimate limiting nutrient for primary production (Fennel and Laurent 2018).

Federal and state agencies are working together with farmers and land managers in the Mississippi River Basin to improve the water quality in their watersheds and to reduce the nutrients and sediment loads to the Mississippi River and the Gulf of Mexico. One USDA Natural Resources Conservation Service (NRCS) program that provides technical and financial assistance to farmers is the Mississippi River Basin Healthy Watersheds Initiative (MRBI) implemented through Cooperative Conservation Partnership Initiatives. The MRBI encourages adoption of conservation practices to improve water quality of the region. This includes NRCS Conservation Activities 201 and 202, which provide financial assistance to agricultural producers who permit field-scale monitoring on their land to determine the effects of management practices on baseline runoff water quality as well as to evaluate effectiveness of conservation practices on soil and water resources (Daniels et al. 2018). These field-scale efforts evaluate environmental performance on individual farms and signify a fundamental move from systematic research toward routine monitoring of practices.

In Arkansas, a statewide network of monitoring at the field scale was established as a
Michele L. Reba is a research hydrologist at the USDA Agricultural Research Service (ARS) Delta Water Management Research Unit, Jonesboro, Arkansas. Niroj Aryal is an assistant professor in the Department of Natural Resources and Environmental Design at North Carolina A\&T State University, Greensboro, North Carolina. Tina Gray Teague is a professor in the College of Agriculture at Arkansas State University, Jonesboro, Arkansas. Joseph H. Massey is a research agronomist at the USDA ARS Delta Water Management Research Unit, Jonesboro, Arkansas. 
result of MRBI programs (Reba et al. 2013). The monitoring projects have focused on establishing baseline water quality information, but they also have served as a catalyst for field-scale research to evaluate crop management practices focused on soil and water conservation. With such data, landowners and business and farm managers should be better equipped to translate applied research, as well as modeling results, to make practical management changes on private and public lands.

Arkansas was an ideal location for the extensive MRBI monitoring activities. The state's agriculture accounts for a larger portion of gross domestic product than for any other state in the nation. For the 2014 calendar year, cash receipts for all Arkansas commodities totaled greater than US\$10 billion. Arkansas produces nearly $50 \%$ of US rice (Oryza sativa L.), and the state also ranks in the top five cotton (Gossypium hirsutum L.) and soybean (Glycine max [L.] Merr.) producing states in the southern United States. Rice production alone adds more than US $\$ 1.5$ billion annually to the state's economy and provides thousands of jobs, primarily in rural communities.

Only a few field studies that relate fertilizer management and crop production to runoff water quality have been conducted in the Mississippi Delta region of eastern Arkansas (Adviento-Borbe et al. 2017, 2018; Aryal et al. 2018; Reba et al. 2013); or the Mississippi Delta region as a whole (Baker et al. 2018; Lizotte and Locke 2018; Osmond et al. 2017). Aryal et al. (2018) included results from edgeof-field monitoring in eastern Arkansas and focused specifically on the impact of cover crops on macronutrient and sediment losses.

Agricultural managers and conservation professionals rely on research-based recommendations to guide decision-making on adoption and effective implementation of management practices to reduce off-site impacts on water quality. Research at the plot scale is ideal for testing management decisions (Moreno-de las Heras et al. 2010; Nesme et al. 2011; Teague and Danforth 2010; Teague et al. 2005) and improving our understanding of water quality dynamics (Jiao et al. 2012; Macdonald et al. 2017). However, findings from plot-scale studies must be confirmed at larger field scales to ensure applicability to commercial production. Research validation can accelerate adoption of innovative practices to increase the impact of research, but studies that include larger plots are often challenged due to lack of data for comparisons at broader scales (Sharpley and Kleinman 2003). Ecosystem processes are scale dependent, and there is always a measure of uncertainty associated with extrapolating from plot to larger scales (Dabney 1998). Water quality studies conducted on the watershed continuum (e.g., field to farm to watershed scale) are difficult to replicate in a statistically significant manner due to cost and limited control (Melland et al. 2018). At the watershed scale, standards for the entire watershed are often derived from select locations in-stream or in-lake. Such studies are important in assessing the overall well-being of in-stream or lake conditions; however, they may not provide site-specific data that are sufficiently resolute to evaluate whether changes in agronomic management practices work to reduce nutrient and sediment losses. Because of data limitations, they often fail to reveal dependable cause and effect relationships for practical consideration or for widespread adaptability.

Additional data from field-scale studies in the Mississippi Delta region are needed to calibrate, verify, and validate modeling efforts, without which it is difficult to ascertain and quantify uncertainty of modelled results. This includes detailed field-scale measurements of nutrient and sediment losses. Expanded calibration and field validation of models (Tomer et al. 2014) will likely generate a higher degree of confidence that effective adaptive management can be used to address sustainability issues and to mitigate departures from norms in climate. Furthermore, it is anticipated that this work will strengthen and support regional and farm level decision-making to expand implementation of specific conservation practices that sustain high water quality and improve economic performance of agricultural production.

In this paper, we summarize results from edge-of-field water quality monitoring sites in northeast Arkansas over multiple seasons. One goal of this work was to add to the limited body of knowledge related to field scale water quality in the humid Midsouth by providing baseline data of runoff sediment and nutrients. These findings will help inform regional budgets of nutrients and sediment loss, and assist regional land managers in directing resources more effectively and efficiently. The specific objectives were to (1) establish average annual concentrations and loads for sediment and nutrients leaving production-sized fields of typical Midsouth row crops, and (2) quantify differences in sediment and nutrients by time of year, crop type, and rotation.

\section{Materials and Methods}

Study Sites. The Lower Mississippi River Basin (LMRB) is the lowest elevation of the six two-digit hydrologic unit codes (HUCs) of the Mississippi-Atchafalaya River Basin and reaches from the confluence of the Ohio to the outlet in the northern Gulf of Mexico. The narrow band along the Mississippi River Alluvial Plain in the LMRB is considered the Delta region. Historically known for cotton production, agriculture has expanded to major production of rice and soybean. The Delta region is characterized by humid subtropical climate with long, hot summers and mild winters. This study was conducted at four commercial farms on nine production-sized fields in the Mississippi Delta region of northeastern Arkansas from 2014 to 2017 (figure 1). All data were collected as baseline information with standard agronomic practices of the region implemented by the cooperating producers. The results represent 23 site-years of data from fields where rice, soybean, and cotton were commercially produced.

The Marked Tree site was located in Poinsett County near Marked Tree, Arkansas. Hydrologically, the site is located in the lower St. Francis watershed (8-digit HUC: 08020203; figure 1). The sites drain into an agricultural feeder ditch and to Ditch Number 1, St. Francis River (12-digit HUC: 080202030801). The research site consisted of three fields ranging in size from 13.6 ha, $16.1 \mathrm{ha}$, and 15.9 ha. Soil mapping information for the fields was obtained from Web Soil Survey (USDA NRCS 2019) and were classified as Sharkey-Steele complex on slopes less than $1 \%$. All soils were characterized as hydrologic soil group D, implying extremely slow permeability and high likelihood of runoff. The study field slopes were $0.15 \%$ and had been precision graded. During the study years, the Marked Tree sites were on a rice-soybean annual rotation, starting in 2014 with rice.

The Manila site was located in Mississippi County near Manila,Arkansas. Hydrologically, the site is located in the Little River Ditches watershed (8-digit HUC: 08020204; figure 1). The site drains into an agricultural feeder ditch and to Ditch Number 14,Buffalo Creek Ditch (12-digit HUC: 080202040803). The research site was created by splitting a large 


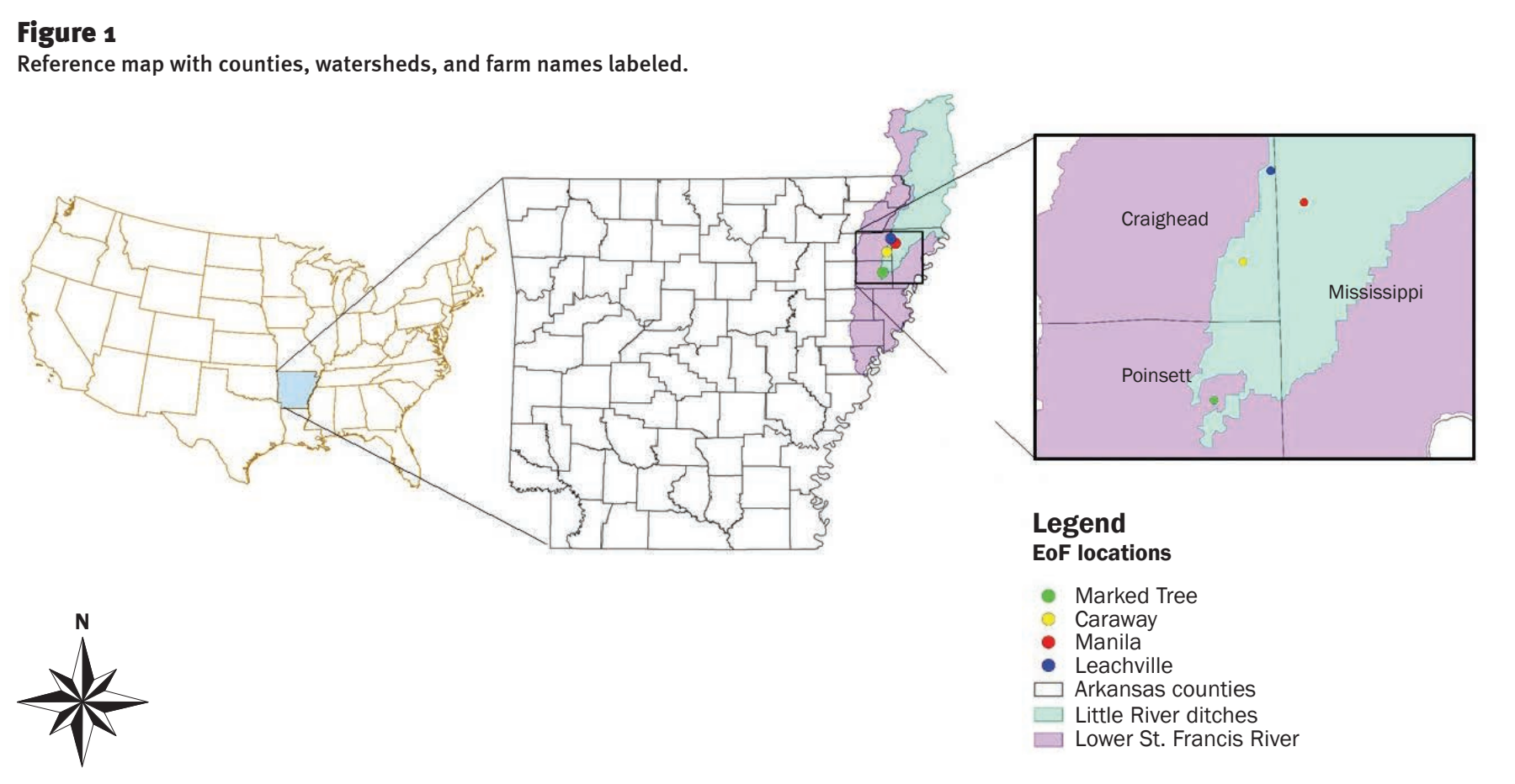

production field into two equally sized fields, each 7.8 ha. Soils for the Manilla site were classified as Routon-Dundee-Crevasse complex and Sharkey-Steele complex on slopes less than $1 \%$. The hydrologic soil group for the Routon-Dundee-Crevasse complex was $\mathrm{C} / \mathrm{D}$ and covered $69.9 \%$ and $66.6 \%$ of each study field, and the Sharkey-Steele complex was D and covered $30.4 \%$ and $33.4 \%$, implying slow permeability and high likelihood of runoff. The study field slopes were $0.15 \%$ and had been precision graded. Data were collected from the Manila site in 2015, 2016, and 2017 when the fields were planted in cotton.

The Leachville site was located in Craighead County near Leachville, Arkansas. Hydrologically, the site is located in the Little River Ditches watershed (8-digit HUC: 08020204; figure 1). The site drains into an agricultural feeder ditch and to Ditch Number 4, Buffalo Creek Ditch (12-digit HUC: 080202040806). The research site was created by splitting a large production field to two equal-sized fields, each 11.7 ha. Again, soil classification information was obtained from Web Soil Survey and was similar in both fields, but was also the most variable of the study. The fields are dominated by sandy loams (Beulah fine sandy loam, Commerce very fine sandy loam, and Mhoon fine sandy loam) with less than approximately one-third of the fields in a silty clay loam (Jackport silty clay loam and Roellen silty clay loam). Soils were characterized as hydrologic soil group A, $\mathrm{C}$, or C/D for the sandy loam and C, C/D, or $\mathrm{D}$ for the silty clay loam, implying excessively drained (A) to poorly drained (C or C/D). Each of the study fields had sandy loam group A on $36.4 \%$ and $21.0 \%, C$ on $29.2 \%$ and $34.8 \%$, and $\mathrm{C} / \mathrm{D}$ on $10.1 \%$ and $1.1 \%$ of the area, respectively. Each of the study fields had silty clay loam group C on $0.2 \%$ and $6.5 \%$, $\mathrm{C} / \mathrm{D}$ on $10.1 \%$ and $4.1 \%$, and $\mathrm{D}$ on $15.6 \%$ and $32.4 \%$ of the study area, respectively. The study field slopes were $0.10 \%$ and had been precision graded. Data were collected from the Leachville site in 2016 and 2017 when the fields were planted in cotton. Corn (Zea mays L.) was grown in the study fields in 2015.

The Caraway site was located in Craighead County near Caraway, Arkansas. Hydrologically, the site is located in the Little River Ditches watershed (8-digit HUC: 08020204; figure 1 . The site drains directly into Ditch Number 56 (12-digit HUC: 080202040807). The research site consisted of two large, adjacent production sized fields that were 31.0 ha and 28.4 ha in size. Soils were similar in both fields and characterized as fine sandy loam. Soils were characterized as hydrologic soil group C/D or D implying slow permeability and high likelihood of runoff. The study fields had been precision graded to have a $0.20 \%$ slopes. Data were collected from the Caraway site in 2015 and 2016 when the fields were planted in soybean. Corn was grown in the study fields in
2014. No data were collected from this site in 2017.

Production Systems. All row crop fields were furrow irrigated on an as-needed basis with groundwater from the Mississippi River Valley Alluvial Aquifer. Records of applied irrigation were not retained for the study fields. A tipping bucket rain gage installed at each site was used to measure the rainfall amount and time stamp the event. Raw precipitation data were post processed to calculate daily totals.

Cotton fields were harvested in the fall (target harvest date for the region typically before November 1). Following harvest and after stalks were shredded, fall tillage practices included use of a disk-bedder to reshape the beds. In spring, broadcast applications of burndown herbicides were made to all fields. Target date of planting for cotton at the study sites was late April through late May. Just prior to planting, tops of beds were flattened with a field cultivator. Seeding rate was approximately 9 seeds $\mathrm{m}^{-1}$ row. Row spacing was $1 \mathrm{~m}$. Broadcast applications of urea were made after plant emergence from late May through early June. Nitrogen was broadcast at all cotton sites in all study years except for 2016 when the $\mathrm{N}$ application was split between broadcast and foliar (table 1). Phosphorus application occurred only at the Manila fields and was applied broadcast in 2015 and variable rate in 2016. 
The first irrigation applications made to cotton typically did not occur until 1 to 2 weeks after commencement of reproductive growth (squaring), which is expected by 35 days after planting. Water furrows were cleared using a Furrow Runner plow (Perkins Sales, Inc., Bernie, Missouri). The Furrow Runner features $50 \mathrm{~cm}$ scalloped disc furrowers, a shovel plow, and a steel packer wheel. Final irrigation typically occurred by late August, the timing of which was related to soil moisture availability and timing of the last effective boll population (cutout). Defoliation for harvest preparation typically occurred in early- to mid-September with harvest following approximately 14 days later, weather permitting.

Soybean fields were prepped in the fall. If the field was in rice, levees were removed, the soil surface smoothed, and beds formed. If the field was previously cropped to cotton, the beds were reshaped with disk bedders using the same tillage practices outlined above for cotton. In spring, broadcast applications of burndown herbicides were made across all fields. Dates of planting ranged from late April to late June while maturity groups ranged from MGIII to MGV. Phosphorus fertilizer was applied by broadcast to one field in 2015 (table 1), and no other fertilizers were applied to the soybean study fields during thus study.

Prior to irrigation, water furrows in the soybean fields were cleared using sweep plows. Soybean irrigation initiation and termination timings were based on plant phenology and soil moisture availability. Irrigation typically was not initiated until the R1 stage. By the R6.5 growth stage, with adequate soil moisture, irrigation was terminated. Harvest dates range from late August through late October depending on maturity group, date of planting, and weather conditions.

Rice in the region is typically grown using a dry-seeded, delayed-flood system (Wilson et al.2016). If the field was previously in soybean, beds were removed, and the soil surface smoothed. In spring, broadcast applications of burndown herbicides were made across all fields. The target date for rice planting was the last week of March but continued into early June. The targeted rice seeding rate was approximately 320 seeds $\mathrm{m}^{-2}$. The fields were precision graded to approximately $0.1 \%$ slopes. The uniform slope allowed use of uniformly spaced, straight levees that divided the fields into separate paddies (Wilson et al.2016).After planting, the levees

\section{Table 1}

Site, year, crop, and fertilizer (nitrogen [N] or phosphorus [P]) applied.

\begin{tabular}{|c|c|c|c|c|}
\hline Site & Year & Crop & $\begin{array}{l}\mathrm{N} \text { fertilizer }\left(\mathrm{kg} \mathrm{ha}^{-1}\right) \text {; } \\
\text { application method }\end{array}$ & $\begin{array}{l}\text { P fertilizer }\left(\mathrm{kg} \mathrm{ha}^{-1}\right) \text {; } \\
\text { application method }\end{array}$ \\
\hline \multirow[t]{2}{*}{ Marked Tree } & 2014 & Rice & 185; split and broadcast & 0 \\
\hline & 2016 & Rice & 137; split and broadcast & 0 \\
\hline \multirow[t]{3}{*}{ Manila } & 2015 & Cotton & 52 ; broadcast & 10; broadcast \\
\hline & 2016 & Cotton & 26; split and foliar & 27 ; variable rate \\
\hline & 2017 & Cotton & 142; broadcast & 0 \\
\hline \multirow[t]{2}{*}{ Leachville } & 2016 & Cotton & 112; broadcast & 0 \\
\hline & 2017 & Cotton & $24 ;$ broadcast & 0 \\
\hline \multirow[t]{2}{*}{ Marked Tree } & 2015 & Soybean & 0 & 0 \\
\hline & 2017 & Soybean & 0 & 0 \\
\hline \multirow[t]{2}{*}{ Caraway } & 2015 & Soybean & 0 & 12 ; broadcast \\
\hline & 2016 & Soybean & 0 & 0 \\
\hline
\end{tabular}

were constructed and levee gates installed. Immediately prior to initial flooding, urea fertilizer was broadcast using a ground rig or by aerial application (table 1). The fields were initially flooded at the four- to five-leaf rice growth stage (Counce et al. 2000), corresponding to late May to early June. Irrigation water was added throughout the growing season as necessary to maintain an approximately 8 to $15 \mathrm{~cm}$ flood depth (Gealy 1998; Smith Jr. and Fox 1973). The floodwaters were drained from the fields approximately two weeks prior to harvest.

Field Setup, Water Sampling, and Water Analysis. The same field equipment for water sampling was deployed at all study sites. Equipment was housed in weather resistant shelters positioned at designated drainage outlets. At all sites, these were drainage grade-control pipes in all instances $(0.38$ to $0.62 \mathrm{~m}$ diameter). The monitored drainage pipe was chosen based on access and maximized the drainage area flowing into it. A water collection apparatus with sensors was mounted to a steel instrumentation sled, which was affixed to the inlet side of each drainage pipe. This instrumentation consisted of a pressure transducer (Acculevel, Keller America, Newport News, Virginia), an area-velocity sensor (2150, Teledyne ISCO, Lincoln, Nebraska), and intake tubing for the water sampler (6712, Teledyne ISCO, Lincoln, Nebraska). These systems were powered by a deep cycle marine battery whose charge was maintained by a $20 \mathrm{~W}$ solar panel. More instrumentation details are given by Aryal et al. (2018).

Water samples were collected from runoff produced by precipitation and/or irrigation. Water depth within the drainage pipe was measured continuously. The other instru- ments began collecting data once depth $(0.04$ $\mathrm{m})$ and flow requirements $\left(50 \mathrm{~m}^{3}\right)$ were met. The water sampler settings were intended to collect samples evenly (equal volumes of flow) throughout the hydrograph of an event, minimizing over- or undersampling of an event and sampling both rising and falling limbs of the hydrograph. Once an event began, the sensors were polled every 10 seconds, and these data were used to generate average values every 15 minutes, which were stored on the datalogger. Site communication was carried out with radios (RF401 Campbell Scientific, Logan, Utah) between fields and with cell modems (AT\&T GSM Network $2 \mathrm{G})$ to the laboratory. An alert was sent wirelessly over the cellular network to inform personnel that an event began. Samples were then picked up from that site within 24 hours of the alert, placed on ice, and delivered to the Ecotoxicology Research Facility at Arkansas State University for analysis.

Runoff samples were analyzed at Ecotoxicology Research Facility using standard methodology and included analysis for suspended sediment concentration (SSC) using ASTM Method D3977-97; total suspended solids using APHA 2540-D; $\mathrm{NO}_{2}$ and $\mathrm{NO}_{3}$ using EPA 353.2, APHA 4500$\mathrm{NO}_{3} \mathrm{I}$, and APHA 4500-NO $\mathrm{B}$; total $\mathrm{N}$ (TN) using EPA 350.1 and APHA 4500-P J; orthophosphate $\left(\mathrm{PO}_{4}\right)$ using EPA 354.1 and APHA 4500-P F; and total P (TP) using EPA 365.4 and APHA 4500-P J (American Public Health Association et al. 2005; American Society of Testing and Materials 1997). The detection limit was $0.01 \mathrm{mg} \mathrm{L}^{-1}$ for $\mathrm{PO}_{4}$ and TP, $0.04 \mathrm{mg} \mathrm{L}^{-1}$ for $\mathrm{NO}_{3}$ and $\mathrm{TN}$, and 0.002 $\mathrm{mg} \mathrm{L}^{-1}$ for $\mathrm{NO}_{2}$.

Routine Maintenance. In addition to when the field technician visited the stations 
to collect runoff samples, the sites were visited every two weeks to inspect and perform routine maintenance, inspect instruments, restock supplies, and to calibrate sample collection volume. Moreover, the stations were visited as soon as possible any time that an alert (e.g., low battery voltage) was sent to notify of maintenance needs.

Data Analysis. For each runoff event, the nutrient and sediment concentrations from the laboratory and the corresponding continuous-flow data were used to calculate the load $\left(\mathrm{kg} \mathrm{ha}^{-1}\right)$ and total load $(\mathrm{kg})$. Reported values of both concentrations and load in the text are median values unless otherwise labeled. All statistical analysis was performed using Sigma Plot version 13.0. Nonnormal data were examined using Mann Whitney Rank Sum Test for two groups, and analysis of variance (ANOVA) on ranks for greater than two groups. Pairwise comparison was done using Dunn's Method whenever the ANOVA results indicated differences between groups.

\section{Results and Discussion}

Precipitation. Total rainfall in years 2014, 2015, 2016, 2017, and 30-year normal rainfall for the Manila site (the most centrally located farm of the study; figure 2) were 1,234, 1,474, 1,204, 1,170, and 1,277 mm, respectively. Therefore, years 2014, 2016, and 2017 were drier than a normal year; however, a closer look at the monthly rainfall (figure 2) in all years revealed that several months were wetter than a normal month, even in a dry year. For example, March of 2016 was wetter than the 30-year average for March, although annually 2016 was drier than the annual 30-year average. November of 2015 was the wettest month with $300 \mathrm{~mm}$ rainfall compared to normal rainfall of $121 \mathrm{~mm}$. October of 2016 has the highest deviation from the 30-year average with an observed rainfall of $34 \mathrm{~mm}$ compared to $104 \mathrm{~mm}$ normal rainfall for the month. Generally, rainfall amounts were low in January, February, September, and October, but variations from year-to-year were observed.

Effect of Season on Pollutant Concentrations and Loads. The median volume of runoff per unit area per event was significantly higher $(p$ $<0.01)$ in the nongrowing season $(7.91 \mathrm{~mm})$ than in the growing season $(4.95 \mathrm{~mm}$; figure 3). Concentrations and loads of SSC, $\mathrm{PO}_{4}-\mathrm{P}$, and TP were also significantly higher in the nongrowing season than in the growing sea-

\section{Figure 2}

(a) Annual rainfall and (b) monthly rainfall observed at Manila site for all study years compared to annual and monthly average rainfall.

(a)

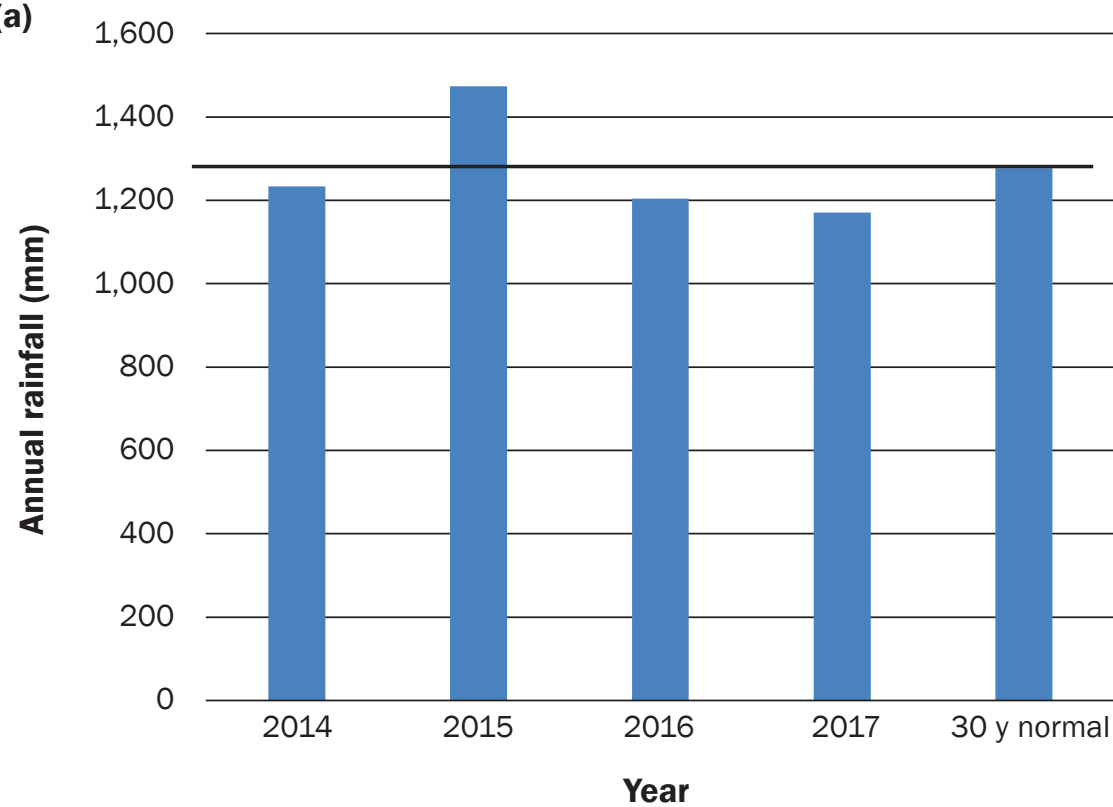

(b)

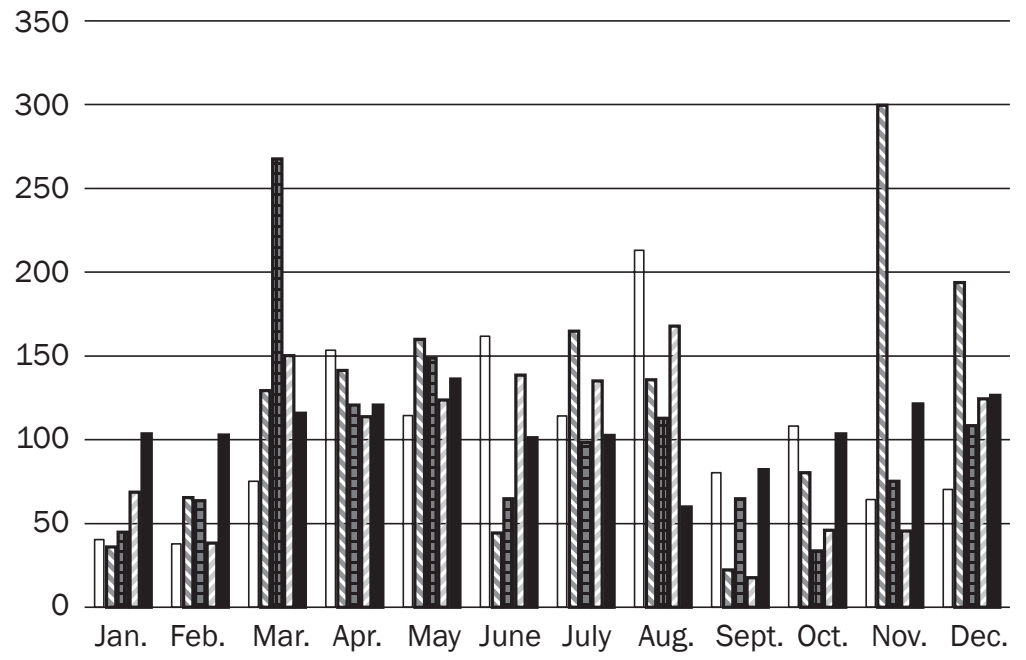

Month

\section{Legend}

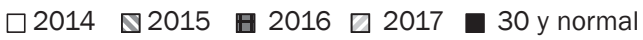

son $(p=0.01$ to 0.02$)$. As for $\mathrm{N}$ species, $\mathrm{TN}$ concentrations per event in the nongrowing season $\left(1.00 \mathrm{mg} \mathrm{L}^{-1}\right)$ were higher than that in the growing season $\left(0.751 \mathrm{mg} \mathrm{L}^{-1} ; p=0.01\right)$. Nitrite and $\mathrm{NO}_{3}$ concentrations and load, and $\mathrm{TN}$ load were not different between growing and nongrowing season.

These results imply that runoff, sediment, $\mathrm{P}$, and $\mathrm{TN}$ loss from fields were higher in the nongrowing season than in the growing season (figure 3). These results concur with our prior results at the field scale (Aryal et al. 2018), as well as at the watershed scale (Aryal and Reba 2017). Timing of pollutant loads has implications for pollution mitigation. For example, nutrient reduction strategies will be effective if targeted to the nongrowing period. A good example is the use of cover crops 


\section{Figure 3}

(a) Concentrations and (b) loads of Pollutant (nitrogen [N], phosphorus [P], and suspended sediment concentration [SSC]), and runoff per event from fields in growing (May to October) and nongrowing season (November to April). The horizontal lines in the box plot represent the $10^{\text {th }}, 25^{\text {th }}$, median, $75^{\text {th }}$, and $90^{\text {th }}$ percentile.

(a)

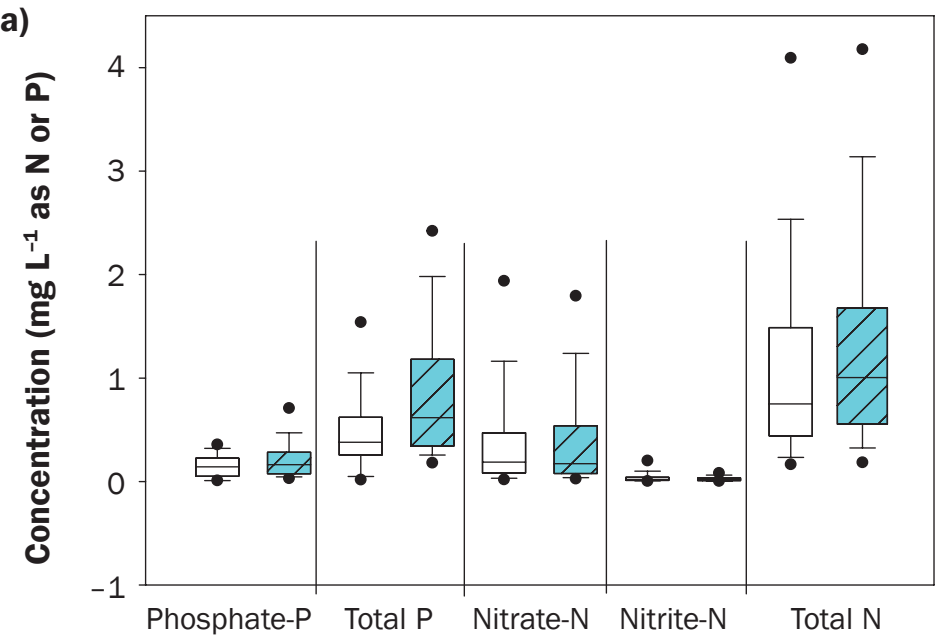

(b)

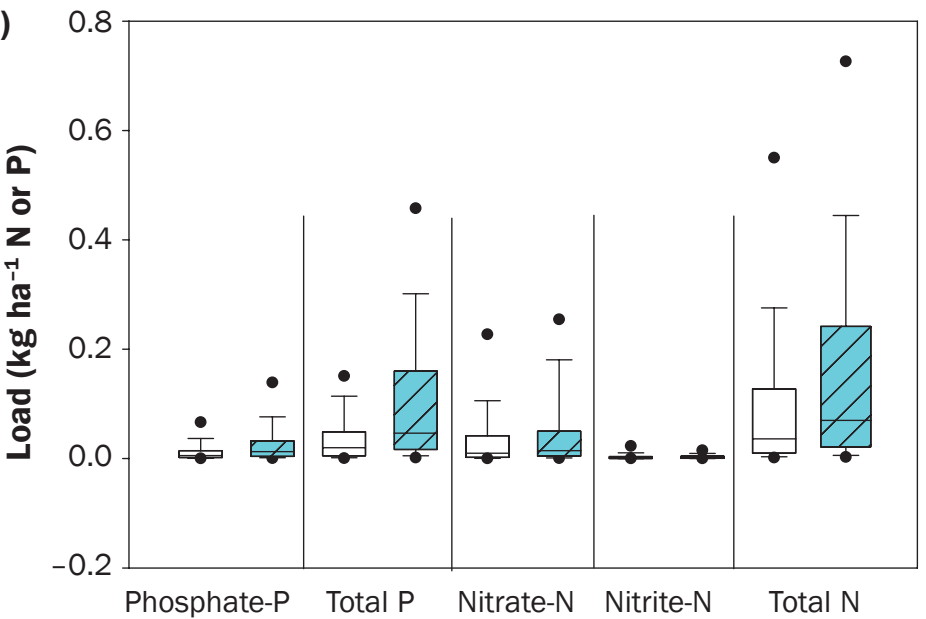

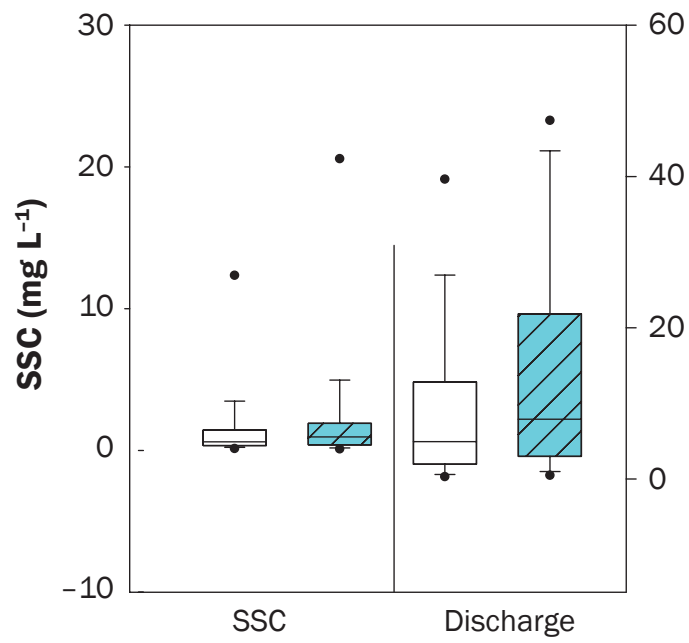

疋

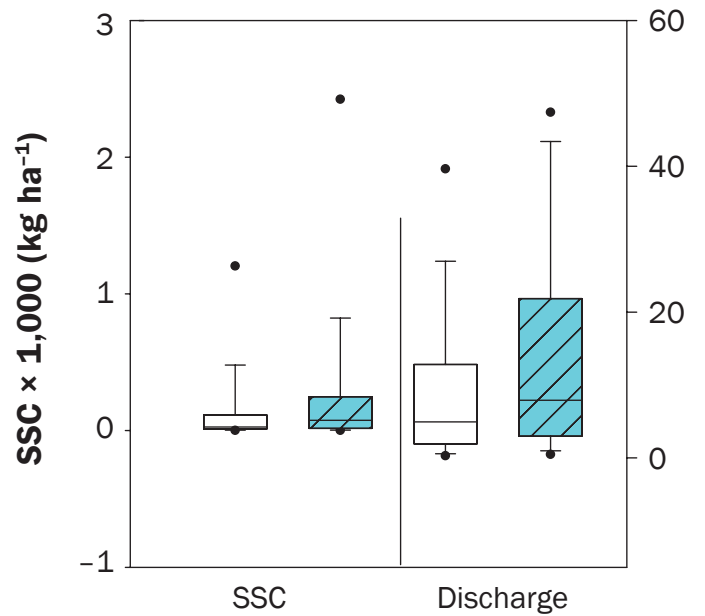

Legend

$\square$ Growing $\longleftarrow$ Nongrowing

that protect soil (Dabney et al. 2001; Kaspar and Singer 2011) during the nongrowing season. Also, the conservation practice called "Shallow Water Development and Management" (USDA NRCS Conservation Practice \#646) occurred in the rice system during the nongrowing season. This practice includes storing storm water runoff on agricultural fields, primarily after rice, during the fallow season. Use of this practice has resulted in a number of agronomic benefits including increased soil retention and improved water quality (Manley et al. 2005); reduced weed pressure, which lowers the need for preplant herbicide applications (Koger et al. 2013); and increased crop $\mathrm{N}$ uptake during the next growing season (Eagle et al. 2000). The practice has also been shown to significantly increase waterfowl species richness and density (Elphick and Oring 2003).

Owing to the importance of $\mathrm{N}$ load $\left(\mathrm{NO}_{3}\right.$ and $\mathrm{NO}_{2}$ load) measured in May at Baton Rouge, Louisiana, to the development of the size of the hypoxic zone in the northern
Gulf of Mexico (Turner et al. 2008), implementing tactics that reduce nutrient losses in early springtime should be emphasized. The most common management practices that occur in this period are tillage and early application of nutrients. In this study, $75 \%$ of the $\mathrm{N}$ application dates occurred after June 1 with the other three occurring from April 29 to May 11. The P application dates were more varied. Of the three application dates of $\mathrm{P}$, one occurred in the fall, one in April, and the other in June. The limited losses 


\section{Figure 4}

Phosphate-phosphorus (P) and total phosphorus (TP) (a) concentrations and (b) loads, and (c) runoff per event from fields by crop. The horizontal lines in the box plot represent the $10^{\text {th }}, 25^{\text {th }}$, median, $75^{\text {th }}$, and $90^{\text {th }}$ percentile.

(a)

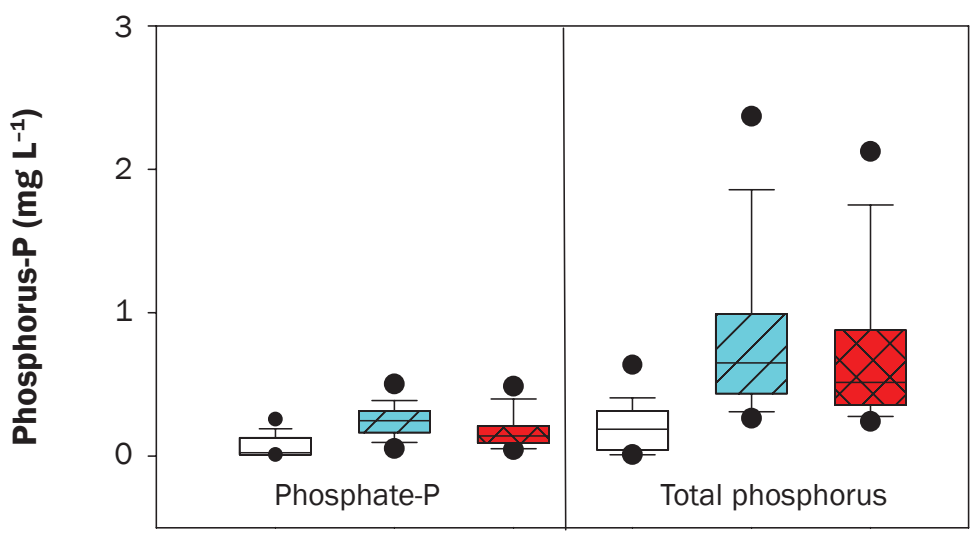

(b)

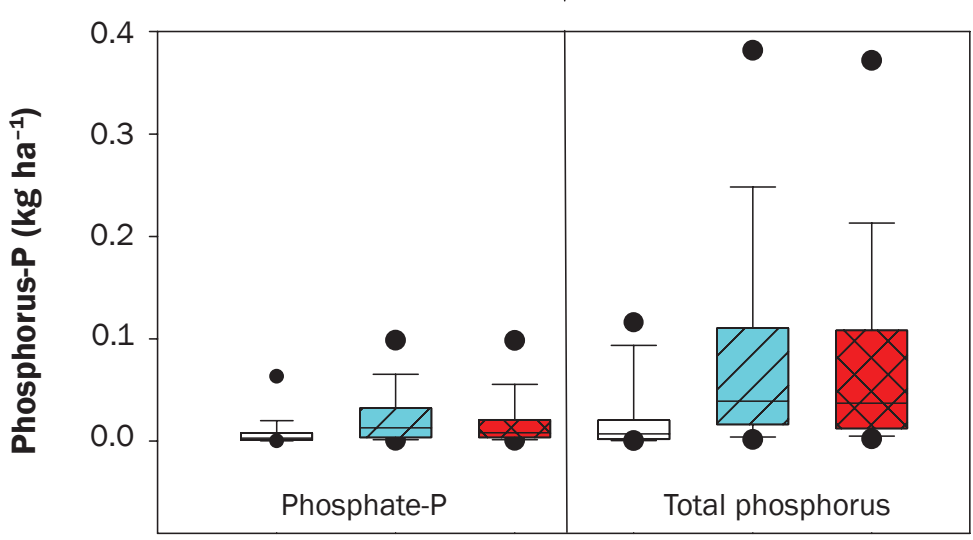

(c)

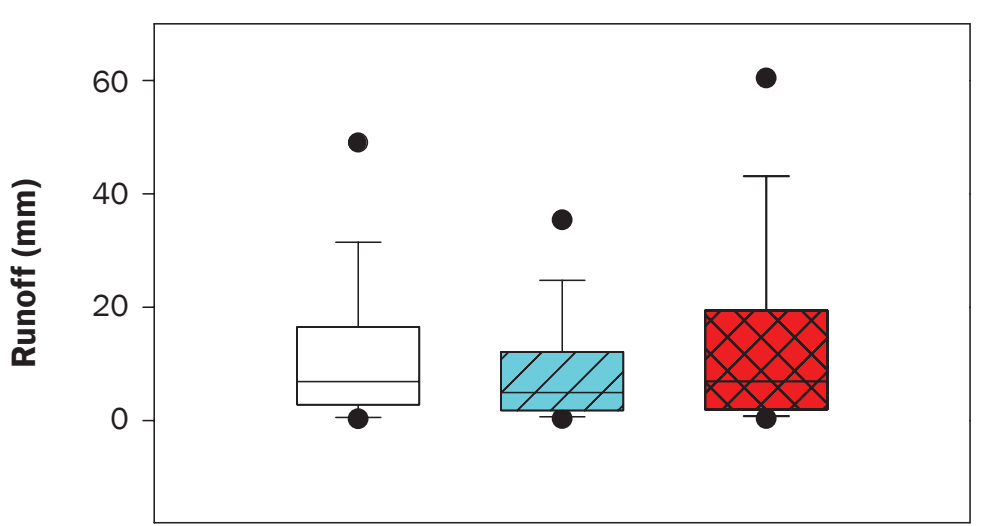

Legend

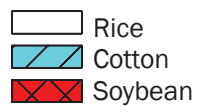

during the growing season suggest that crop canopy and crop demand for applied nutrients tended to reduce nutrient runoff losses. Care should be taken in overgeneralizing based on these results, however. Jordan et al. (2012) reported that mobilization and transfer potential were more important than $\mathrm{P}$ availability. Also, these factors increased delivery due to flashiness (Jordan et al. 2005). Increased mobilization coupled with expected increases in precipitation intensity, as illustrated through the prevalence of extreme, single-day precipitation events (USEPA 2016), has been shown to result in increased runoff losses of sediment and nutrients in runoff. Therefore, special care should be exercised when applying these $\mathrm{N}$ and $\mathrm{P}$ nutrients in the spring when intense precipitation events are more common.

Pollutant Loads from Different Cropping Systems. Nutrients, water, and sediment losses were compared to determine if differences in magnitude existed among fields planted in rice, soybean, and cotton in commercial production scenarios. This analysis did not consider differences in rainfall, soils, nor crop rotation between locations. Instead, the analysis represents the current management practices that farmers in the study adopted for each crop. The comparison provides the current nutrient concentrations and loads received by waterbodies using a large number of events for each crop. The numbers of runoff events measured in rice, cotton, and soybean fields at all sites were 113, 150, and 200, respectively. However, actual numbers of events for pollutant loading were lower due to missing discharge information during some events. The runoff events where loading of pollutants were available in rice, cotton, and soybean were 83,127 , and 189 , respectively.

Phosphate-P concentrations in the runoff per event were highest from cotton fields $\left(0.248 \mathrm{mg} \mathrm{L}^{-1}\right)$, followed by soybean $(0.142$ $\left.\mathrm{mg} \mathrm{L}^{-1}\right)$, and rice $\left(0.024 \mathrm{mg} \mathrm{L}^{-1}\right)$ (figure 4). Each was significantly different from the others $(p<0.001)$. Similarly, TP concentration was highest from cotton fields $\left(0.650 \mathrm{mg} \mathrm{L}^{-1}\right)$, followed by soybean $\left(0.514 \mathrm{mg} \mathrm{L}^{-1}\right)$, and rice $\left(0.188 \mathrm{mg} \mathrm{L}^{-1}\right)$. Total $\mathrm{P}$ from cotton was not statistically higher than that from soybean $(p$ $=0.06)$, but both cotton and soybean had significantly higher TP than rice $(p<0.001)$.

The discharge per event from soybean, rice, and cotton was $6.93,6.93$, and $4.93 \mathrm{~mm}$, respectively, and these values were not statistically different from each other in one-way ANOVA on ranks $(p=0.231)$. Phosphate-P load per event in cotton $\left(0.013 \mathrm{~kg} \mathrm{ha}^{-1}\right)$ and soybean fields $\left(0.008 \mathrm{~kg} \mathrm{ha}^{-1}\right)$ were greater than that in rice fields $\left(0.002 \mathrm{~kg} \mathrm{ha}^{-1}\right)(p<$ $0.001)$; however, they were not different from each other $(p=0.36)$. Similarly, TP load in cotton $\left(0.040 \mathrm{~kg} \mathrm{ha}^{-1}\right)$ and soybean fields $\left(0.037 \mathrm{~kg} \mathrm{ha}^{-1}\right)$ were greater than that in rice fields $\left(0.007 \mathrm{~kg} \mathrm{ha}^{-1} ; p<0.01\right)$, but they were not different from each other $(p=0.99)$. 


\section{Figure 5}

Nitrate-nitrogen ( $\mathrm{N}$ ), nitrite- $\mathrm{N}$, and total $\mathrm{N}(\mathrm{a})$ concentrations and (b) loads, and (c) runoff per event from fields by crop. The horizontal lines in the box plot represent the $10^{\text {th }}, 25^{\text {th }}$, median, $75^{\text {th }}$, and $90^{\text {th }}$ percentile.

(a)

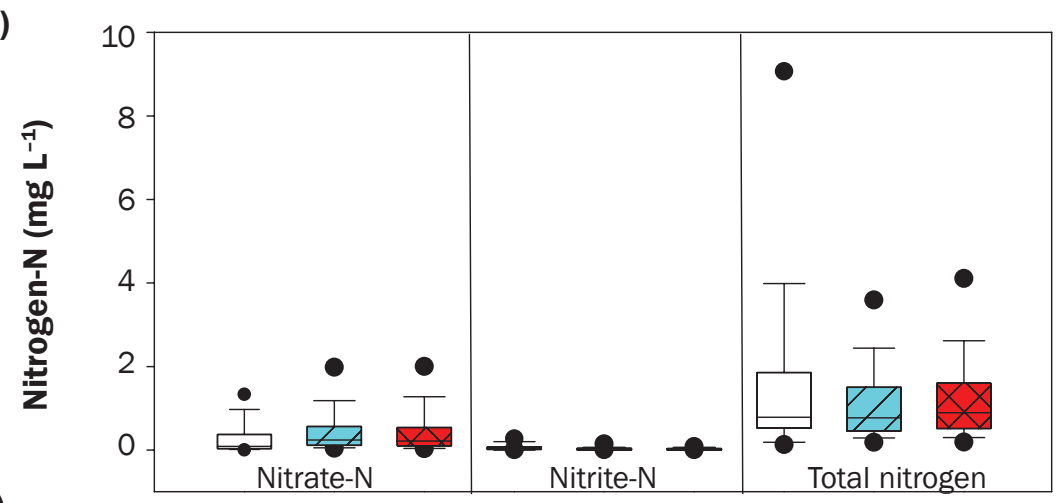

(b)

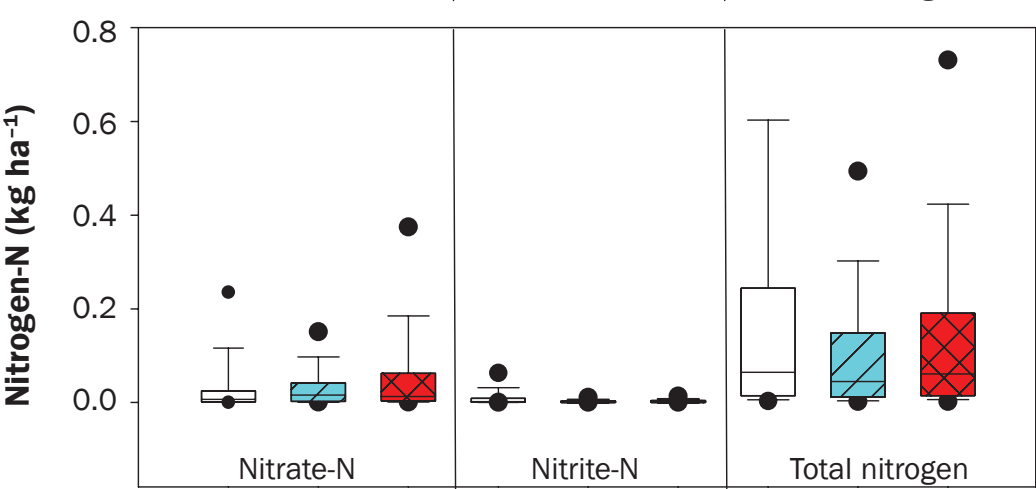

(c)

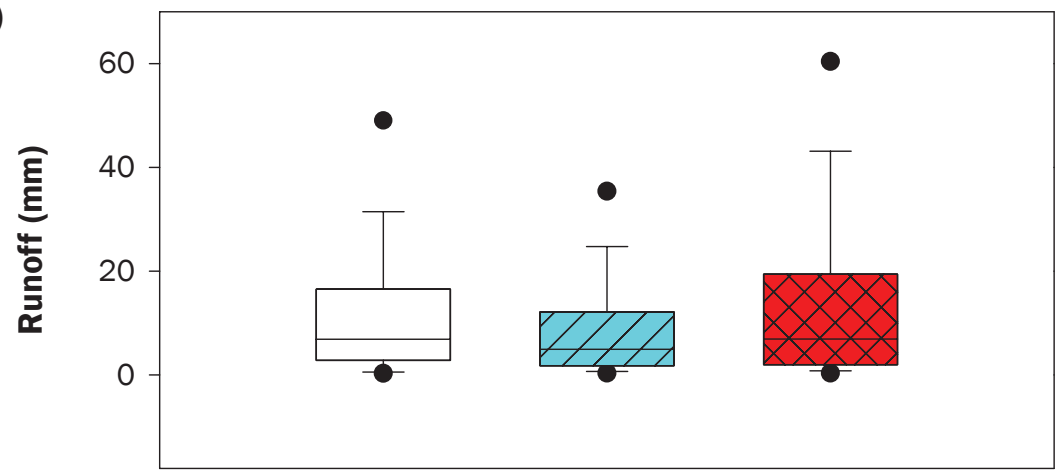

\section{Legend}

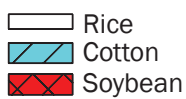

Among the three crops studied, rice had significantly lower concentrations and loads of pollutants while cotton had the highest. Factors including soils, topography, weather, and management can all affect the magnitude of pollutants in the runoff. For example, rice is generally grown on impermeable silty clay to clayey soils where cotton production would not be suitable.
Conversely, cotton is grown on sandy loam soils whose excessive infiltration would make rice production economically infeasible owing to the high irrigation water demand. Though not measured in this study, additional gaseous losses of $\mathrm{N}$ from rice are expected, owing to denitrification and ammonium $\left(\mathrm{NH}_{4}\right)$ losses from $\mathrm{NH}_{4}-$ based fertilizers (Sommer et al. 2004).
Nitrate- $\mathrm{N}, \mathrm{NO}_{2}-\mathrm{N}$, and $\mathrm{TN}$ concentrations from rice fields were $0.088,0.032$, and $0.786 \mathrm{mg} \mathrm{L}^{-1}$; from cotton fields were 0.238 , 0.018 , and $0.772 \mathrm{mg} \mathrm{L}^{-1}$; and from soybean fields were $0.215,0.0175$, and $0.895 \mathrm{mg} \mathrm{L}^{-1}$, respectively (figure 5). Nitrate- $\mathrm{N}$ concentrations in cotton and soybean fields were greater than that in rice fields $(p<0.001)$; however, they were not different from each other $(p>0.05)$. Nitrite- $\mathrm{N}$ was significantly higher from rice fields compared to both cotton and soybean fields $(p<0.01)$, but soybean and cotton fields were not statistically different $(p>0.05)$. Total $\mathrm{N}$ concentrations from cotton, soybean, and rice were not statistically different $(p=0.68)$. These findings agree generally with those of Jiao et al. (2012), when they compared wheat (Triticum aestivum $\mathrm{L}$.)/corn, wheat/cotton, and wheat/ soybean runoff at plot scale over three years on an experiment station in China. These authors found the highest losses of $\mathrm{NO}_{3}$ and TN occurred from wheat/cotton and the lowest occurred from wheat/soybean. However, the magnitudes of $\mathrm{NO}_{3}-\mathrm{N}$ and TN concentrations reported by Jiao et al. (2012) were approximately 2.5 times greater than those measured in the present study for cotton and soybean.

Nitrate- $\mathrm{N}, \mathrm{NO}_{2}-\mathrm{N}$, and $\mathrm{TN}$ loads from rice fields were $0.007,0.002$, and $0.061 \mathrm{~kg}$ $\mathrm{ha}^{-1}$; from cotton fields were 0.016, 0.001, and $0.045 \mathrm{~kg} \mathrm{ha}^{-1}$; and from soybean fields were $0.013,0.001$, and $0.062 \mathrm{~kg} \mathrm{ha}^{-1}$, respectively (figure 5). Nitrate- $\mathrm{N}$ loads in rice fields were significantly lower than that in cotton and soybean fields $(p=0.03)$; however, cotton and soybean fields were not statistically different from each other $(p>0.09)$. Nitrite load of cotton was significantly lower than that of rice $(p=0.01)$, but not than that of soybean $(p=0.57)$. Soybean and rice had statistically similar $\mathrm{NO}_{2}$ load $(p=0.16)$. Total $\mathrm{N}$ loads from cotton, soybean, and rice were not statistically different $(p=0.33)$.

Nitrate-N losses were greater from cotton and soybean fields than from rice fields, whereas, $\mathrm{NO}_{2}-\mathrm{N}$ loss were greater from rice fields than from cotton and soybean fields. As a result, TN losses were similar from each cropped field.

Concentrations and loads of SSC from rice fields were $0.587 \mathrm{mg} \mathrm{L}^{-1}$ and $26.43 \mathrm{~kg}$ $\mathrm{ha}^{-1}$; from cotton fields were $0.782 \mathrm{mg} \mathrm{L}^{-1}$ and $43.40 \mathrm{~kg} \mathrm{ha}^{-1}$; and from soybean fields were $0.805 \mathrm{mg} \mathrm{L}^{-1}$ and $56.56 \mathrm{~kg} \mathrm{ha}^{-1}$, respectively (figure 6). Only concentration of SSC 
from soybean and rice fields were different from each other $(p=0.03)$, with rice lower. No other pair-wise comparisons for either concentrations or loads were statistically significant ( $p=0.09$ to 0.75 ).

Water and nutrient management in rice is inherently different from that of furrow-irrigated row crops such as cotton and soybean. It has been found that rice fields have similar functional equivalency with that of seminatural wetland habitats (Elphick 2000). In rice, nutrients are not generally applied until immediately before flood establishment, which occurs approximately 30 days after planting. Once the rice flood is established, producers generally maintain a near constant flood depth throughout the growing season. Irrigation water management in straight-levee rice fields fosters creation of freeboard to capture rainfall (Massey et al. 2019). When rice flood management is optimized, little, if any, water leaves the field. This is somewhat similar to water management in Australia, which prohibits the return of irrigation water to the river system (Kennedy et al. 2013). Thus, rice flood management is more likely to retain sediment and reduce runoff while the standing rice flood reduces raindrop impact and soil gouging as compared to furrow irrigation.

Effect of Cropping System and Rotation on Same Field at Marked Tree. An annual rotation of rice and soybean was practiced in the fields at Marked Tree. This allowed for an analysis of the effects that crop, in this case rice and soybean, had on the concentrations and loads of pollutants from the same fields (figure 7). Rice was grown in 2014 and 2016, whereas soybean was grown in 2015 and 2017. Precipitation in 2015 and 2017 was the highest and lowest annual total, respectively, of the study. The years 2014 and 2016 were very near the annual average precipitation and were 43 and $73 \mathrm{~mm}$ less, respectively, than the annual average.

Total $\mathrm{P}$ and $\mathrm{PO}_{4}-\mathrm{P}$ concentrations per runoff event were significantly lower from rice seasons than from soybean seasons $(p<$ 0.03). Among $\mathrm{N}$ species, $\mathrm{TN}$ and $\mathrm{NO}_{2}-\mathrm{N}$ from both cropping systems were not statistically different $(p>0.05)$. However, $\mathrm{NO}_{3}-\mathrm{N}$ concentrations from rice crops were significantly lower than that from soybean crops, most likely due to increased denitrification due to prolonged flooding. Total $\mathrm{N}$ concentrations were significantly greater than $\mathrm{NO}_{3}$

\section{Figure 6}

(a) Concentrations and (b) loads of suspended sediment concentrations (SSC) and (c) runoff per event from fields by crop. The horizontal lines in the box plot represent the $10^{\text {th }}$, $25^{\text {th }}$, median, $75^{\text {th }}$, and $90^{\text {th }}$ percentile.

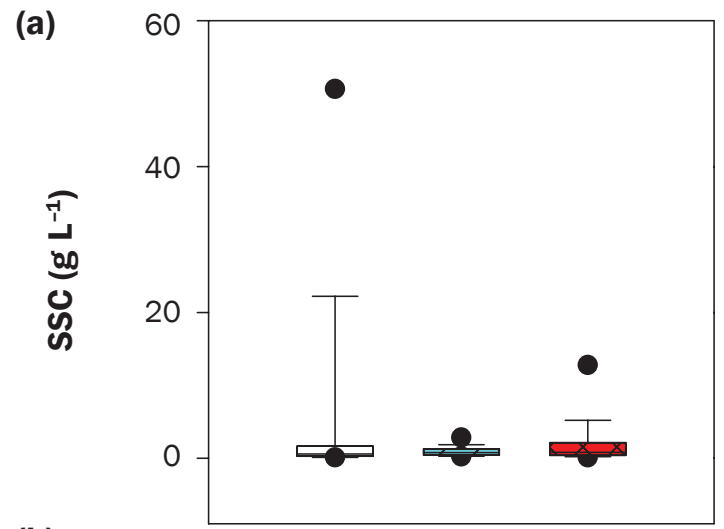

(b)

(c)
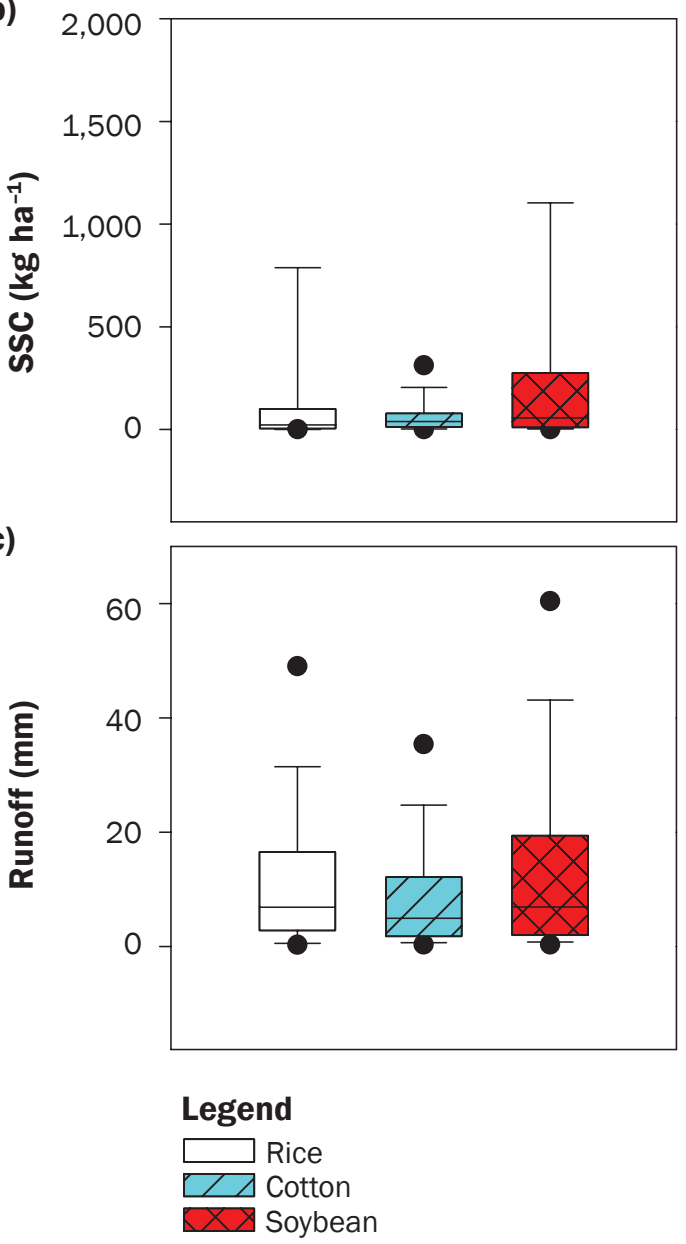

concentrations $(p<0.001)$ in rice fields but not in soybean fields $(p=0.21)$, implying that $\mathrm{NO}_{3}-\mathrm{N}$ was a minor contributor to $\mathrm{TN}$ in rice cropping and a major contributor in soybean cropping. Concentrations of SSC and discharge per runoff event was significantly lower in rice cropping system than in soybean $(p<0.01)$. Therefore, runoff from rice cropping systems had lower discharge, $\mathrm{PO}_{4}-\mathrm{P}, \mathrm{TP}, \mathrm{NO}_{3}-\mathrm{N}$, and SSC than those from 
Figure 7

(a) Concentrations and (b) loads of Pollutant (nitrogen [N], phosphorus [P], and suspended sediment concentration [SSC]), and runoff per event from Marked Tree fields during rice and soybean growing season. The horizontal lines in the box plot represent the $10^{\text {th }}, 25^{\text {th }}$, median, $75^{\text {th }}$, and $90^{\text {th }}$ percentile.

(a)

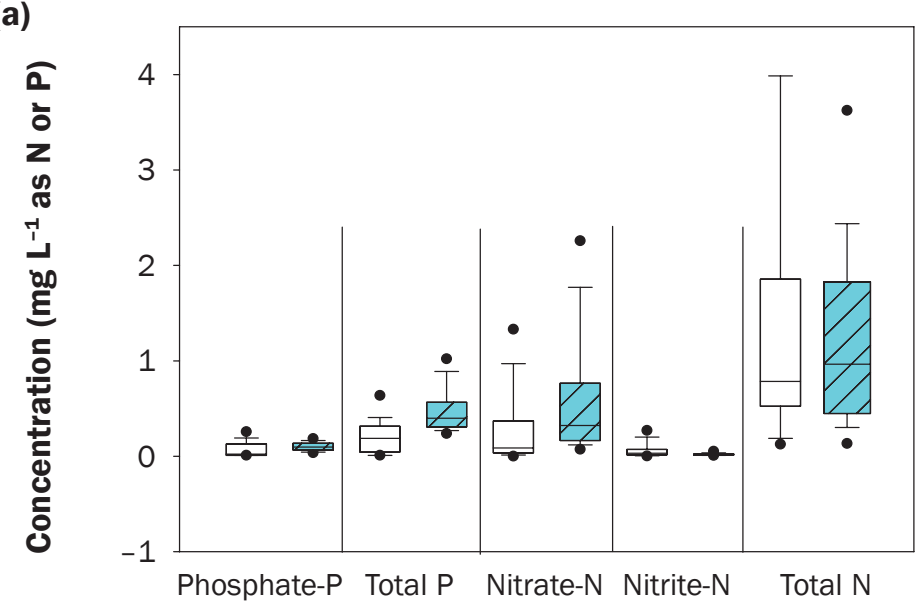

(b)

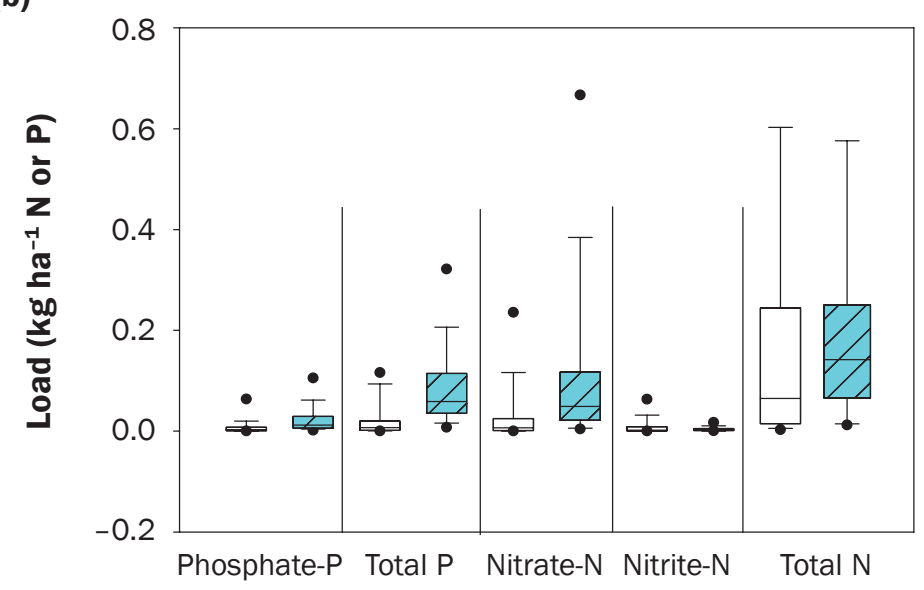

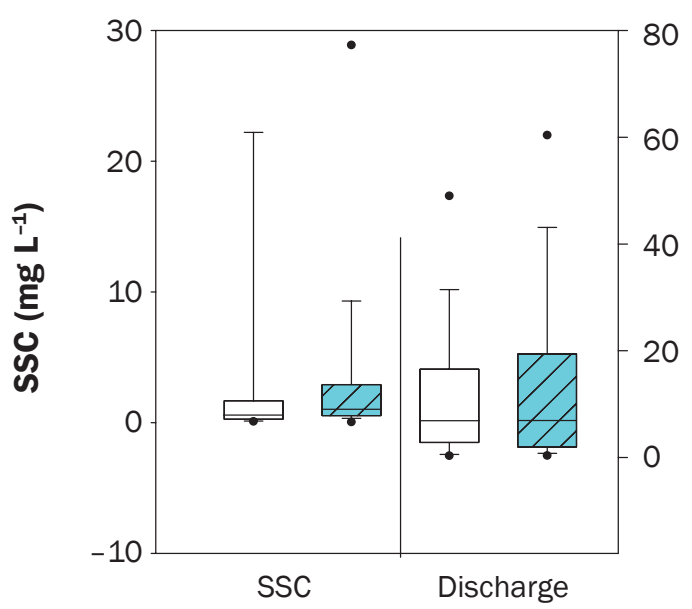

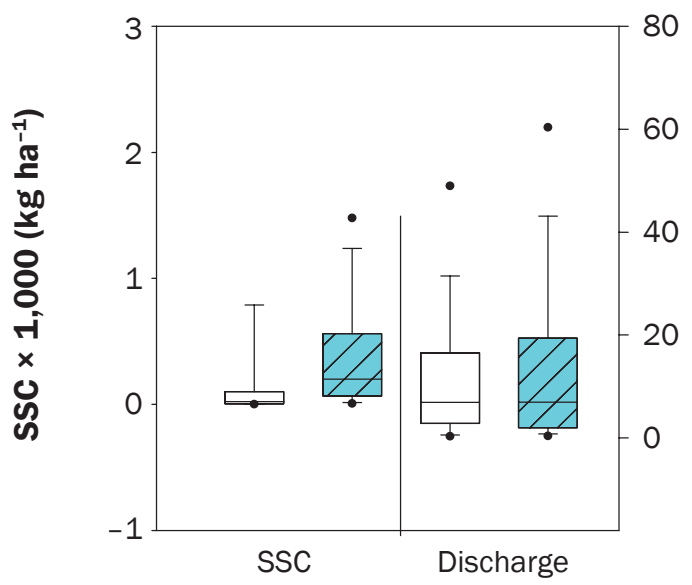

Legend

$\square$ Rice $\quad$ Soybean

soybean. Differences in runoff could also be attributed to differences in precipitation of the years studied with soybean grown during the year with the greatest precipitation. However, TN losses were similar between the two cropping systems.

Pollutant loads also followed similar patterns as loads of $\mathrm{PO}_{4}-\mathrm{P}, \mathrm{TP}, \mathrm{NO}_{3}-\mathrm{N}$, and SSC were significantly lower from the rice cropping system than from the soybean cropping system $(p<0.01)$, but TN loads were similar from both cropping systems $(p=0.34)$. Past studies support our observation as $\mathrm{NO}_{3}$ and $\mathrm{NH}_{4}$ from soybean were lost at the rate of $1.43 \mathrm{mg} \mathrm{L}^{-1}$ and $0.57 \mathrm{mg} \mathrm{L}^{-1}$, respectively, in the surface runoff from a 0.3 ha watershed in a chisel plow tillage system (Shipitalo et al. 2013). In contrast, median concentrations of $\mathrm{NO}_{3}$ and $\mathrm{NH}_{4}$ from a rice field were 0.25 and $0.7 \mathrm{mg} \mathrm{L}^{-1}$, respectively (Das et al. 2009).

Effect of Soil on Pollutant Concentrations and Loads for Soybean. Effects of soil texture on pollutant loads and concentrations were assessed by comparing two sites (Marked Tree and Caraway), both under soybean cropping in 2015 (figure 8). Marked Tree has 100\% clay complex soil, whereas Caraway has mostly sandy loam soil. Precipitation in 2015 was higher than the annual average and the greatest amount of annual precipitation of this study. The previous crops were rice at Marked Tree and corn at Caraway. In-season fertilizer was the same at both sites with no additional nutrients added. However, $\mathrm{P}$ was added in the early fall at Caraway.

Phosphate-P and TP were not different from each other ( $p=0.2$ to 0.53$)$ regardless of soil and differences in fertilizer, but $\mathrm{PO}_{4}-\mathrm{P}$ concentration was lower than TP concentration at both sites $(p<0.001)$. Total $\mathrm{N}$, $\mathrm{NO}_{3}-\mathrm{N}$, and $\mathrm{NO}_{2}-\mathrm{N}$ concentrations from the two soils were not different $(p>0.05)$. Additionally, concentrations of SSC were not different from the two soils $(p=0.19)$ despite higher magnitude from clay soils. 


\section{Figure 8}

(a) Concentrations and (b) loads of Pollutant (nitrogen [N], phosphorus [P], and suspended sediment concentration [SSC]), and runoff from heavy (clay) and light (sandy loam) textured soils under soybean plantation after rice on clay soil or corn on sandy loam soil. The horizontal lines in the box plot represent the $10^{\text {th }}, 25^{\text {th }}$, median, $75^{\text {th }}$, and $90^{\text {th }}$ percentile.

(a)
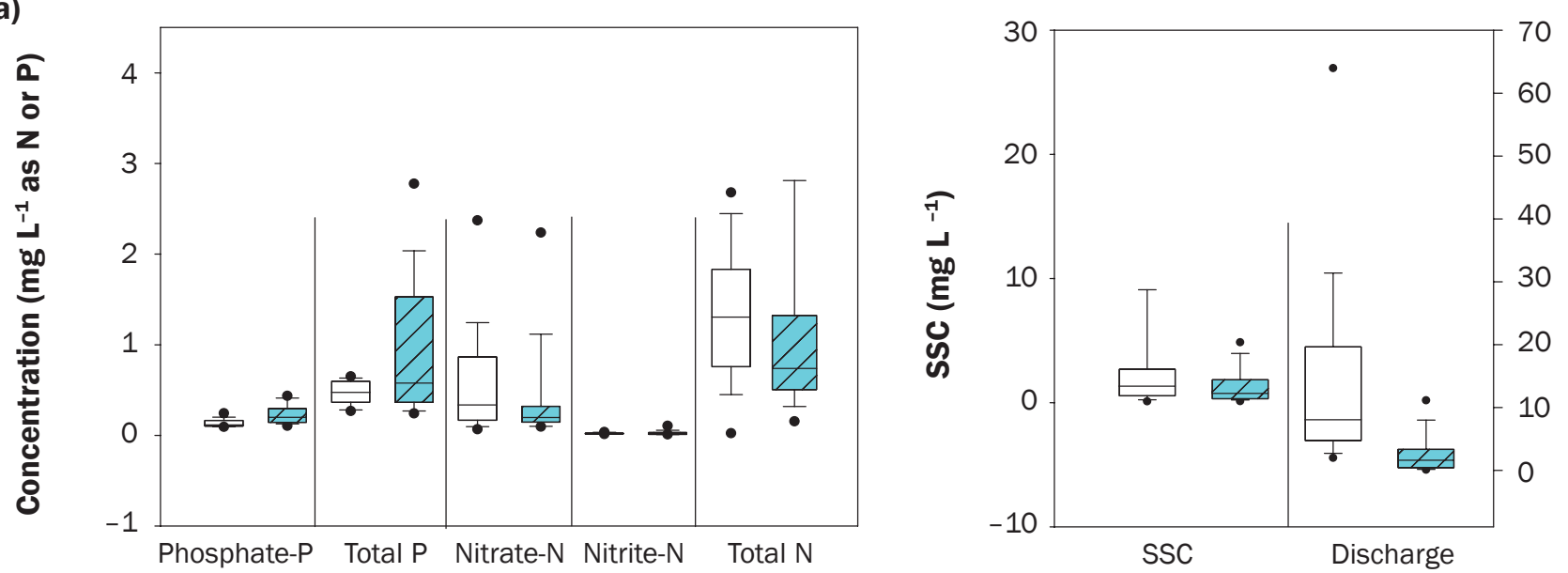

(b)
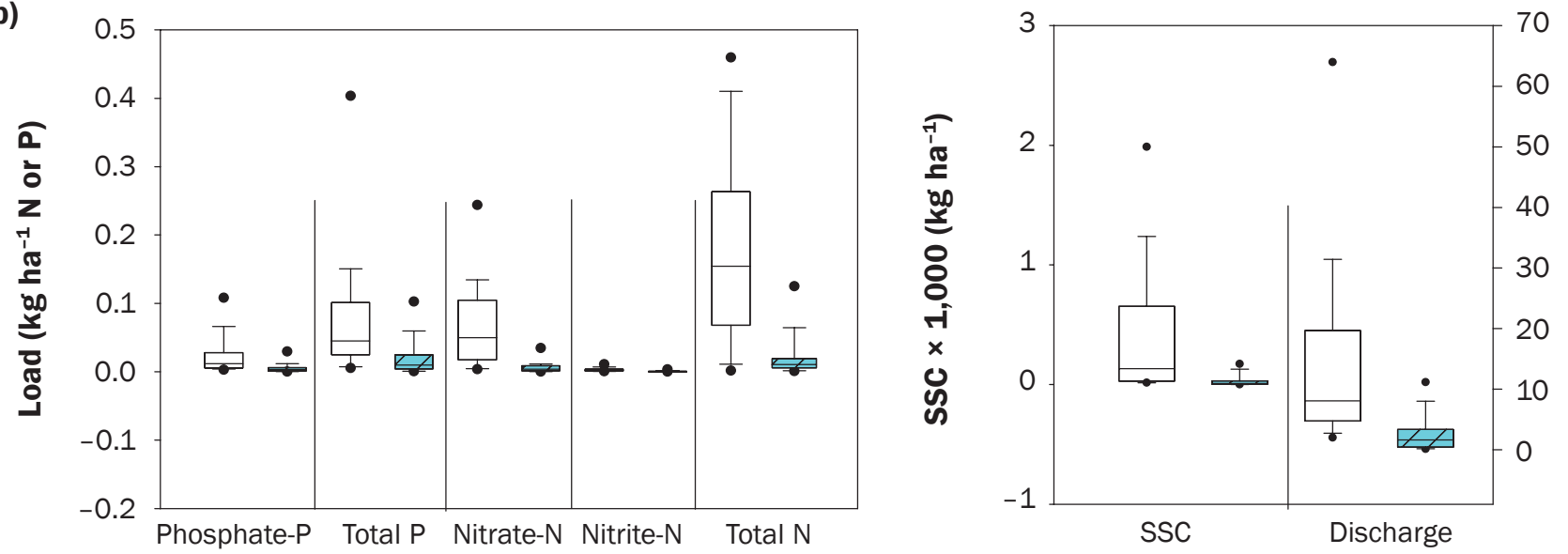

Legend

$\rightleftarrows$ Clay $\longleftarrow$ Sandy loam

The differences in fertilizer and previous crop had little impact on the resulting runoff water quality measured.

As expected, discharge from clayey soils was higher than that from sandy loam $(p<$ $0.01)$. Due to the higher runoff discharge volume, loads of $\mathrm{PO}_{4}-\mathrm{P}, \mathrm{TP}, \mathrm{NO}_{3}-\mathrm{N}, \mathrm{TN}$, and SSC were higher from clay soils than from sandy loam soils $(p<0.05)$ under soybean after rice in clay soils than after corn in sandy loam soils.

\section{Summary and Conclusions}

The work presented in this manuscript will add to the limited body of knowledge related to field-scale water quality in the humid mid-South.

1. Runoff, sediment, $\mathrm{P}$, and TN loss from fields were higher in the nongrowing season than in the growing season, which implies that corrective practices that target the nongrowing season, such as winter cover crops or winter flooding of fields for waterfowl, are important considerations. Losses in the spring are also important as they influence the regional issue of hypoxia in the northern Gulf of Mexico and precipitation events that transport nutrients and sediment are more common during this time.
2. Among the three crops investigated, rice had significantly lower concentrations and loads of pollutants while cotton generally had the highest. Flooded rice fields more effectively held water on the field and reduced the amounts of runoff and nutrient losses compared to furrow-irrigated cotton and soybean fields. Additional gaseous losses of $\mathrm{N}$ from rice were not measured here but are expected, owing to denitrification.

3. Comparisons within rice-soybean rotation common to the LMRB revealed that pollutant loads and concentrations 
were lowest during the rice phase of the rotation. These differences can be mainly attributed to water management and that the flooded rice system effectively acts as a constructed wetland to capture rainfall and reduce soil erosion.

4. Soil texture did not seem to affect observed pollutant concentrations but may impact the mass loads of pollutants. Higher loads were observed from clay texture soils as compared to sandy soils. This was likely related to increased runoff volumes observed from less permeable clayey soils.

5. The data presented in this study can be used to calibrate, verify, and validate modeling efforts specific to the Mississippi Delta region of the LMRB.

\section{Acknowledgements}

The research team acknowledges USDA Natural Resources Conservation Service Mississippi River Basin Healthy Watershed Initiative, the Environmental Quality Incentives Program (EQIP), and the Conservation Effects Assessment Project (CEAP) Watershed Assessment Studies for financially contributing to implementation, monitoring, and assessment for this project. We also are grateful to the collaborating producers who allowed the sample collection on their farms. We extend our appreciation to members of Delta Water Management Research Unit, USDA Agricultural Research Service (ARS), specifically Geoffrey Payne, Yin-Lin Jack Chiu, Ian Godwin, and Nadine Straitt, for field collection of samples and maintenance of the sites. Thank you to the University of Arkansas Agricultural Experiment Station, Jonesboro, for research assistance. We appreciate the staff and administration at the Ecotoxicology Research Facility at Arkansas State University for sample analysis.

Part of this research was supported by an appointment to the ARS Participation Program administered by the Oak Ridge Institute for Science and Education (ORISE) through an interagency agreement between the US Department of Energy (DOE) and the USDA. ORISE is managed by Oak Ridge Associated Universities (ORAU) under DOE contract number DE-AC05-06OR23100. This research was also supported by the USDA Agricultural Research Service National Program 211.

\section{Disclaimer}

All opinions expressed in this paper are the authors' and do not necessarily reflect the policies and views of USDA, ARS, DOE, or ORAU/ORISE.

\section{References}

Adviento-Borbe, M.A., B.D. Barnes, O. Iseyemi, A.M. Mann, M.L. Reba,W.J. Robertson, J.H. Massey, and T.G.Teague, 2018. Water quality of surface runoff and lint yield in cotton under furrow irrigation in Northeast Arkansas, Science of the Total Environment 613:81-87.

Adviento-Borbe, M.A., H.Wood,M.L.Reba,J.H.Massey, and

T.G. Teague. 2017. Influence of tillage practices on lint yield, water quality, and soil exchangeable $\mathrm{N}$ in cotton production. In Summaries of Arkansas Cotton Research, 2017, ed. F. Bourland. Fayetteville, AR: University of Arkansas, Arkansas Agricultural Experiment Station.

American Public Health Association, American Water Works Association, and Water Environment Federation. 2005. Standard Methods for the Examination of Water and Wastewater. Washington, DC: American Public Health Association.

American Society of Testing and Materials. 1997. Standard Test Methods for Determining Sediment Concentration in Water Samples. West Conshohocken, PA: ASTM International.

Aryal, N., and M.L. Reba. 2017.Transport and transformation of nutrients and sediment in two agricultural watersheds in Northeast Arkansas, Agriculture, Ecosystems, and Environment 236:30-42, doi:10.1016/j. agee.2016.11.006.

Aryal, N., M.L. Reba, N. Straitt, T.G. Teague, J. Bouldin, and S. Dabney. 2018. Impact of cover crop and season on nutrients and sediment in runoff water measured at the edge of fields in the Mississippi Delta of Arkansas. Journal of Soil and Water Conservation 73(1):24-34, doi:10.2489/jswc.73.1.24.

Baker, B.H., J.P. Czarnecki, A.R. Omer, C.A. Aldridge, R. Kröger, and J.D. Prevost. 2018. Nutrient and sediment runoff from agricultural landscapes with varying suites of conservation practices in the Mississippi Alluvial Valley. Journal of Soil and Water Conservation 73(1):7585, doi:10.2489/jswc.73.1.75.

Counce, P.A., T.C. Keisling, and A.J. Mitchell. 2000. A uniform, objective, and adaptive system for expressing rice development. Crop Science 40:436-443.

Dabney, S. 1998. Cover crop impacts on watershed hydrology. Journal of Soil and Water Conservation 53(3):207-213.

Dabney, S.M., J.A. Delgado, and D.W. Reeves. 2001. Using winter cover crops to improve soil and water quality. Communications in Soil Science Plant Analysis 32(7 \& 8):1221-1250.

Daniels, M., A. Sharpley, R.D. Harmel, and K. Anderson. 2018. The utilization of edge-of-field monitoring of agricultural runoff in addressing nonpoint source pollution. Journal of Soil and Water Conservation 73(1):1-8, doi:10.2489/jswc.73.1.1.

Das, P., J.H. Sa, K.H. Kim, and E.C. Joen. 2009. Effect of fertilizer application on ammonia emission and concentration levels of ammonium, nitrate, and nitrite ions in a rice field, Environmental Monitoring and Assessment 154(1-4):275-282.

Douglas, C.L., K.A. King, and J.F. Zuzel. 1998. Nitrogen and phosphorus in surface runoff and sediment from a wheat-pea rotation in northeastern Oregon. Journal of Environmental Quality 27:1170-1177, doi:10.2134/ jeq1998.00472425002700050023x.

Eagle, A.J., J.A. Bird, W.R. Horwath, B.A. Linquist, S.M. Brouder, J.E. Hill, and C. Van Kessel. 2000. Rice yield and nitrogen utilizatione efficiency under alternative straw management practices. Agronomy Journal 92:1096-1103, doi:10.2134/agronj2000.9261096x.

Elphick, C.S. 2000. Functional equivalency between rice fields and seminatural wetland habitats. Conservation Biology 14(1):181-191

Elphick, C.S., and L.W. Oring. 2003. Conservation implications of flooding rice fields on winter waterbird communites. Agriculture, Ecosystems \& Environment 94:17-29, doi:10.1016/S0167-8809(02)00022-1.

Faganeli, J., A. Avčin, N. Fanuko, A. Malej,V. Turk, P. Tušnik, B. Vrišer, and A. Vukovič. 1985. Bottom layer anoxia in the central part of the Gulf of Trieste in the late summer of 1983. Marine Pollution Bulletin 16(2):7578, doi:10.1016/0025-326X(85)90127-4.

Fennel, K., and A. Laurent. 2018. N and P as ultimate and proximate limiting nutrients in the northern Gulf of Mexico: Implications for hypoxia reduction strategies. Biogeosciences 15(10):3121-3131, doi:10.5194/ bg-15-3121-2018.

Gealy, D. 1998. Differential response of palmleaf morninglory (Ipomoea wrightii) and pitted morninglory (Ipomoea lacunose) to flooding. Weed Science 46:217-224.

Jiao, P., D. Xu, S. Wang, Y. Wang, K. Liu, and G. Tang. 2012. Nitrogen loss by surface runoff from different cropping systems. Soil Research 50:58-66, doi:10.1071/SR 11152.

Jordan, P., A.R. Melland, P.E. Mellander, G. Shortle, and D. Wall. 2012. The seasonality of phosphorus transfers from land to water: Implications for trophic impacts and policy evaluation. Science of the Total Environment 434:101-109, doi: 10.1016/j.scitotenv.2011.12.070.

Jordan, P., W. Menary, K. Daly, G. Kiely, G. Morgan, P. Byrne, and R. Moles. 2005. Patterns and processes of phosphorus transfer from Irish grassland soils to rivers-itegration of laboratory and catchment studies. Journal of Hydrology 304:20-34, doi:10.1016/j.jhydrol.2004.07.021.

Kaspar, T.C., and J.W. Singer. 2011. The use of cover crops to mange soil. In Soil Management: Building a Stable Base for Agriculture, eds. J.L. Hatfield and T.J. Sauer, 409. Madison, WI: American Society of Agronomy and Soil Science Society of America.

Kennedy, I.R., M.T. Rose, A. Crossan, and M. Burns. 2013. Research and practice: Environmental action for improving water quality in cotton catchments since 1990. Crop and Pasture Science 64:1095-1111, doi:10.1071/CP13091

Koger, C.H., R.M. Zablotowicz, M.A. Weaver, M.R.TuckerPatterson, J.L. Krutz, T.W. Walker, and J.E. Street. 2013. Effect of winter flooding on weeds, soybean yield, straw degradation, and soil chemical and biochemical characteristics. American Journal of Plant Sciences 4(7):10-18, doi:10.4236/ajps.2013.47A2002. 
Larsson, U.R., R. Elmgren, and F.Wulff. 1985. Eutrophication and the Baltic Sea: Causes and consequences. Ambio 14(1):9-14, https://www.jstor.org/stable/4313091.

Lizotte, R.E., and M.A. Locke. 2018. Assessment of runoff water quality for an integrated best management practice system in an agricultural watershed. Journal of Soil and Water Conservation 73(3):247-256, doi:10.2489/ jswc.73.3.247.

Macdonald, B.C.T., A.J. Ringrose-Voase, A.J. Nadelko, M. Farrell, S. Tuomi, and G. Nachimuthu. 2017. Dissolved organic nitrogen contributes significantly to leaching from furrow-irrigated cotton-wheat-maize rotations. Soil Research 55(1), doi:10.1071/sr16047.

Manley, S.W., R.M. Kaminski, K.J. Reinecke, and P.D. Gerard. 2005.Agronomic implications of waterfowl management in Mississippi rice fields. Wildlife Society Bulletin 33:981-992, doi:10.1127/0941-2948/2006/0167.

Massey, J.H., M.C. Smith, M.A. Adviento-Borbe, M.L. Reba, and L.A. Avila. 2019. Using rainfall analysis to manage freeboard and increase rainfall capture for multiple-inlet rice irrigation in the Lower Mississippi River Valley. Journal of Irrigation and Drainage Engineering 145(8):04019015, doi:10.1061/(ASCE) IR.1943-4774.0001403

Mateo-Sagasta, J., S.M. Zadeh, H. Turral, and J. Burke. 2017. Water pollution from agriculture: A global review. Executive summary. Rome, Italy, and Colombo, Sri Lanka: Food and Agriculture Organization of the United Nations (FAO) and International Water Management Institute (IWMI).

Melland, A.R., O. Fenton, and P. Jordan. 2018. Effects of agricultural land management changes on surface water quality: A review of meso-scale catchment research. Environmental Science and Policy 84:19-25, doi:10.1016/j.envsci.2018.02.011.

Moore, M.T., R.E. Lizotte, S.S. Knight, S.S. Smith, and C. M Cooper. 2007. Assessment of pesticide contamination in three Mississippi Delta oxbow lakes using Hyalella azteca. Chemosphere 67(11):2784-2191.

Moreno-de las Heras, M., J.M. Nicolau, L. MerinoMartin, and B.P. Wilcox. 2010. Plot-scale effects on runoff and erosion along a slope degradation gradient. Water Resouces Research 46:W04503, doi:10.1029/2009WR007875.

Nesme, T., S. Brunault, A. Mollier, and S. Pellerin. 2011. An analysis of farmers' use of phosphorus fertiliser in industrial agriculture: A case study in the Bordeaux region (south-western France). Nutrient Cycling in Agroecosystems 91(1):990-108, doi: 10.1007/ s10705-011-949.

Osmond, D.L., C. Bolster, A. Sharpley, M. Cabrera, S. Feagley, A. Forsberg, C. Mitchell, R. Mylavarapu, J.L. Oldham, D.E. Radcliffe, and J.J. Ramirez-Avila. 2017. Southern Phosphorus Indices, water quality data, and modeling (APEX, APLE, and TBET) results: A comparison. Journal of Environmental Quality 76(6):1296-1305.
Rabalais, N.N., R.E. Turner, and D. Scavia. 2002. Beyond science into policy: Gulf of Mexico hypoxia and the Mississippi River. BioScience 52(2):129-142.

Reba, M.L., M. Daniels, Y. Chen, A.N. Sharpley, J. Bouldin, T.G. Teague, P. Daniel, and C.G. Henry. 2013. A statewide network for monitoring agricultural water quality and water quantity in Arkansas. Journal of Soil and Water Conservation 68(2):45A-49A, doi:10.2489/ jswc.68.2.45A.

Rebich, R.A., N.A. Houston, S.V. Mize, D.K. Pearson, P.B Ging, and C.E. Hornig. 2011. Sources and delivery of nutrients to the Northwestern Gulf of Mexico from streams in the South-Central United States. Journal of American Water Resources Association 47(5):10611086, doi:10.1111/j.1752-1688.2011.00583.x.

Sharpley, A., and P. Kleinman. 2003. Effect of rainfall simulator and plot scale on overland flow and phosphorus transport. Journal of Environmental Quality 32:2182-2179.

Shipitalo, M.J., L.B. Owens, J.V. Bonta, and W.M. Edwards. 2013. Effect of no-till and extended rotation on nutrient losses in surface runoff. Soil Science Society of America Journal 77(4):1329-1337.

Smith Jr., R.J., and W.T. Fox. 1973. Soil water and growth of rice and weeds. Weed Science 21:61-63.

Sommer, S.G., J.K. Schjoerring, and O.T. Denmead. 2004. Ammonia emission from mineral fertilizers and fertilized crops. Advances in Agronomy 82:557-622, doi:10.1016/ S0065-2113(03)82008-4.

Teague, T.G., S. Coy, and D. M. Danforth. 2005. Interactions of water deficit stress and tarnished plant bug induced injury in Midsouth cotton, paper presented at Beltwide Cotton Conference, Memphis, TN.

Teague, T.G., and D.M. Danforth. 2010. Irrigation timing and tarnished plant bug management-Implications for late season susceptibility to tarnished plant bug and crop termination decisions-Year II. Paper presented at Beltwide Cotton Conferences, Memphis, TN.

Tolmazin, D. 1985. Changing coastal oceanography of the Black Sea. I. Northwestern Shelf. Progress in Oceanography 15:217-276.

Tomer, M.D., E.J. Sadler, R.E. Lizotte, R.B. Bryant, T.L. Potter, M.T. Moore, T.L. Veith, C. Baffaut, M.A. Locke, and M.R. Walbridge. 2014. A decade of conservation effects assessment research by the USDA Agricultural Research Service: Progress overview and future outlook Journal of Soil and Water Conservation 69(5):365-373, doi:10.2489/jswc.69.5.365.

Turner, R.E., N.N. Rabalais, and D. Justic. 2008. Gulf of Mexico Hypoxia: Alternate states and a legacy. Environmental Science and Technology 42:2323-2327.

USDA NRCS (Natural Resources Conservation Service. 2019. Web Soil Survey. Washington, DC: USDA Natural Resources Conservation Service. https://websoilsurvey. sc.egov.usda.gov/App/WebSoilSurvey.aspx.

USEPA (US Environmental Protection Agency). 2016. Climate Change Indicators in the United States.
Washington, DC: US Environmental Protection Agency. www.epa.gov/climate-indicators.

USEPA. 2009. National Water Quality Inventory. Report to Congress, 2004 Reporting Cycle. Washington, DC: US Environmental Protection Agency.

Wilson, C.E., Jr., Y. Wamishe, G. Lorenz, and J.T. Hardke. 2016. Arkansas Rice Production Handbook, ed. J. T. Hardke. Fayetteville, AR: University of Arkansas Division of Agriculture, University of Arkansas. 